\title{
HUBUNGAN KEKERABATAN TUMBUHAN FAMILI CUCURBITACEAE BERDASARKAN KARAKTER MORFOLOGI DI KABUPATEN PIDIE SEBAGAI SUMBER BELAJAR BOTANI TUMBUHAN TINGGI
}

\author{
Zufahmi $^{1}$, Ervina Dewi ${ }^{2}$, Zuraida ${ }^{3}$ \\ 1,2Program Studi Pendidikan Biologi, FKIP Universitas Jabal Ghafur \\ ${ }^{1}$ zufahmibio@gmail.com, ${ }^{2}$ vinaunigha@gmail.com, ${ }^{3}$ raidazuraida4@gmail.com
}

\begin{abstract}
ABSTRAK
Cucurbitaceae merupakan tumbuhan yang dapat tumbuh di daerah dataran tinggi maupun dataran rendah. Memiliki kandungan gizi yang tinggi dan serat buah yang halus sehingga mudah dicerna, banyak digunakan sebagai obat tradisional sebagai anti diabetes, anti hipertensi, anti tumor, immunomodulasi, dan anti bakteri karena banyak mengandung nutrisi dan senyawa bioaktif seperti fenolat, flavonoid, vitamin (termasuk vitamin $\beta$-karoten, vitamin $A$, vitamin B2, $\alpha$-tokoferol, vitamin $\mathrm{C}$, dan vitamin $\mathrm{E}$ ), asam amino, karbohidrat dan mineral (terutama kalium), kandungan energi rendah (sekitar $17 \mathrm{Kcal} / 100 \mathrm{~g}$ labu segar) dan serat dalam jumlah yang besar. Tujuan penelitian ini adalah untuk mengetahui hubungan kekerabatan jenis tumbuhan famili Cucurbitaceae berdasarkan karakter morfologi di Kabupaten Pidie. Penelitian dilaksanakan pada Juni-Agustus 2018 di Kabupeten Pidie, terdiri dari Kecamatan Pidie, Mila, Indrajaya, Peukan Baro, Mutiara, dan Tangse. Pengamatan morfologi dilakukan dengan mengamati organ batang, daun, bunga, buah dan biji. Analisis data dengan menggunakan software UPGMA NTSYS untuk memperoleh dendrogram hubungan kekerabatan. Hasil penelitian menunjukkan bahwa ditemukan 8 (delapan) jenis tumbuhan famili Cucurbitaceae terdiri dari Cucumis sativus (mentimun), Luffa acutangula (gambas/oyong), Ligenaria siceria (labu air), Cucurbita moschata (waluh), Sechium edule (labu siam), Citrullus vulgaris (semangka), Cucumis melo (melon), dan Momordica charantia (pare). Karakterisasi morfologi pada tumbuhan famili cucurbitaceae menunjukkan adanya variasi morfologi pada organ batang, daun, bunga, buah dan biji. Pada koefisien kemiripan 0.67, dendogram dibagi menjadi 4 (empat) kelompok. Kelompok 1 terdiri dari Cucumis sativus (mentimun), Luffa acutangula (gambas/oyong), Ligenaria siceria (labu air), dan Citrullus vulgaris (semangka). Kelompok 2 terdiri dari Cucurbita moschata (waluh) dan Cucumis melo (melon). Kelompok 3 terdiri dari Sechium edule (labu siam). Kelompok 4 terdiri dari Momordica charantia (pare).
\end{abstract}

Kata kunci: Cucurbitaceae, Karakter Morfologi, Dendogram

\section{PENDAHULUAN}

Cucurbitaceae merupakan tumbuhan yang dapat tumbuh di daerah dataran tinggi maupun dataran rendah. Jenis tumbuhan ini dapat tumbuh dengan baik pada daerah yang kering dengan curah hujan sedang, dan pada ketinggian 1000-3000-meter diatas permukaan laut (dpl). Karena memiliki daya adaptasi yang tinggi, maka tanaman ini dapat tumbuh di mana saja (Purba, 2008). Terdiri dari 130 genus dan 800 spesies. Genus yang termasuk dalam family ini terdiri dari Trichosanthes, Lagenaria, Luffa, Benincasa, Momordica, Cucumis, Citrullus, Cucurbita,
Bryonopsis dan Corallocarpus. Beberapa jenis tumbuhan yang telah dilakukan penelitian adalah Momordica charantia, Cucurbita pepo, Cucumis sativus, Cucumis melo, Citrullus colocynthis, Luffa echinata, Trichosanthes kirilowii, Lagenaria siceraria, Beninca sahispida (Saboo, et.al: 2003).

Botani Tumbuhan Tinggi merupakan salah satu mata kuliah pada Program Studi Pendidikan Biologi Universitas Jabal Ghafur yang mempelajari tentang taksonomi (sistematika) tumbuhan tingkat tinggi. Pemahaman materi taksonomi relative sulit untuk dipelajari karena mahasiswa belum 
memahami konsep dasar keanekaragaman hayati. Belajar dari alam bukan berarti hanya dapat memperhatikan gejala-gejala yang ditimbulkan oleh alam saja, tetapi dapat juga digunakan sebagai tempat untuk melakukan proses belajar mengajar, dan sebagai alat pendukung dalam proses pembelajaran yang berkaitan dengan alam.

Menurut Efendi (2013), lingkungan alam sifatnya relatif menetap, oleh karena itu jenis lingkungan ini akan lebih mudah dikenal dan dipelajari oleh anak. Sesuai dengan kemampuannya, anak dapat mengamati perubahan-perubahan yang terjadi dan dialami dalam kehidupan seharihari, termasuk juga proses terjadinya. Karakter morfologi digunakan untuk mengidentifikasi tumbuhan Cucurbitaceae yang meliputi batang, daun, buah, dan biji, sehingga dapat diketahui variasi yang terdapat pada tumbuhan tersebut.

Tujuan penelitian ini adalah untuk mengetahui hubungan kekerabatan jenis tumbuhan famili Cucurbitaceae berdasarkan karakter morfologi. Manfaat dari penelitian ini adalah sebagai sumber data yang dapat digunakan dalam koleksi plasma nutfah tumbuhan familI Cucurbitaceae. Karakterisasi morfologi tumbuhan familI Cucurbitaceae dapat digunakan sebagai data yang akurat, sehingga dapat mendukung program pemuliaan tanaman.

\section{KAJIAN LITERATUR}

Tanaman famili cucurbitacea (keluarga labu-labuan) terdiri dari 120 genus dan memiliki lebih dari 800 spesies. Persebaran hidupnya di domiminasi pada iklim tropis, hanya sedikit di iklim sedang. Pada umumnya bersifat liana yang memanjat dengan sebagian besar liana berbatang herbaceous dan ada juga liana berkayu lunak, serta terdapat alat tambahan pada tunas berupa sulur (tendril) (Teppner,2004). Tendril akan menggumpar sehingga membantu menyangga tumbuhan tersebut (Campbell, 2010). Variatas labu-labuan antaranya spesies Cucurbita pepo, Cucurbita maxima, Cucurbita moschata, dan Cucurbita mixta (Deyo, 2008). Spesies yang lain antara lain Citrullus lanatus, Cucumis sativus, Luffa acutangula, Momordica charantia, dan Cucurbita digiata.

Batang cucurbitacea merupakan tanaman herba tahunan atau berumur lebih panjang, menjalar atau memanjat kadangkadang sebagian besar diantaranya berkayu lunak. karakteristik cucurbita melo berwarna hijau muda dengan bentuk batang agak bersegi lima berlekuk dengan 3 -7 lekukan dan bergaris tengah $8 \mathrm{~cm}-15 \mathrm{~cm}$. batangnya berhulu dan tedapat buku atau ruas - ruas tempat melekatnya tangkai daun. karekterisasi labu kuning dapat diketahui bahwa warna batang berwana hijau tua, bentuk batang semuanya segitiga, sifat batang umumnya berair, permukaan batang kasar, dan arah tumbuh. Batang pare dapat mencapai panjang $\pm 5 \mathrm{~cm}$ dan berbentuk segilima. (Suwarto, 2010).

Daun (leaf) pada kebanyak tumbuhan vaskular merupakan organ fotosintetik utama, walaupun batang hijau melakukan fotosintetik (Campbell, 2010). Bentuk daun sangat bervariasi namun biasanya terdiri dari atas sebuah helaian (blade) pipih dengan satu tangkai daun (petiole). Pada umumnya organ daun cucurbitacea berperan dalam proses fotosintetik dan memiliki daun tunggal serta umumnya susunan daun berselang-seling. Lebih lanjut Parmiarso (2012), menyatakan bahwa mentimun (Cucumis sativus) memiliki daun tunggal dengan bagian runcing menyerupai bentuk seperti jantung, tepi daun bergerigi, kedudukan daun pada berselang-seling antara satu daun dengan daun di atasnya serta tumbuh keluar dari ruas batang. Panjang daun antara 7-18 cm. Daun melon berwarna hijau dengan bentuk daun bercangkap atau menjari bersudut lima, berlekuk 3-5 lekukan dan ebrgaris tengah 8$15 \mathrm{~cm}$. Daun ditopong dengan tangkai daun yang perpajangannya merupakan induk tulang daun, permukaan daun berbulu kasar, dan susunan daun berselang-seling.

Bunga merupakan alat reproduksi seksual. Bunga dikatakan lengkap apabila mempunyai daun kelopak, daun mahkota, benang sari, putik, dan daun buah. Bunga terdiri atas bagian fertil, yaitu benang sari dan 
daun buah, serta bagian yang steril yaitu daun kelopak dan daun mahkota. Karakteristik dari famili cucurbitacea memiliki bunga berkelamin tunggal (uniseksual) aktinomod ada hypathium, sangat jarang berkelamin ganda, Kelopak bunga lengket, mahkota berdaun lengket, tabung mahkota tumbuh bersatu dengan tabung kelopak., umumnya 5 sepal dan petal, petal umumya bersatu atau lepas dari stamen, Filamen lepas atau bersatu, begitu pula pada anteranya,ovarium inferior, plasenta parietalis atau plasenta bersatu di tengah sehingga plurilotulen (Olson,2013).

Buah secara normal terbentuk dari perkembangan setelah pembuahan, dimana bakal buah meluas kearah plasenta dan ovarium. Ukuran buah bertambah disebabkan oleh adanya 2 proses, yakni pembelahan sel (yang diawali oleh membesarnya sel, sebelum pembelahan mitosis) dan pembesaran sel berikutnya. Pembesaran sel tergantung, biasanya awal terjadinya pada pembelahan sel, dan dimulai sebelum antesis, kemudian berlanjut sampai buah sesungguhnya. Tingkat ini kemudian secara berangsur menuju pada pembentangan sel, dan diikuti oleh pertumbuhan memanjang.

Karakteristik bentuk biji tanaman cucurbitacea salah satu biji mentimun berbentuk pipih, kulitnya berwarna putih atau putih kekuning - kuningan sampai coklat. Biji ini dapat digunakan sebagai alat perbanyakan tanaman (Cahyono, 2006). Biji mentimun permukaan berlendir sehingga untuk pembenihan harus dikeringkan. Biji buah umumnya berwarna cokelat muda panjangnya rata-rata $0,9 \mathrm{~mm}$ dan diameter $0,4 \mathrm{~mm}$. Pada umumnya satu melon terdapat sekitar 500-600 biji. Karakteristik morfologi labu kuning dari bentuk biji, panjang biji, lebar, warna biji memiliki perbedaan karena adanya lingkungan dan geografi (Suwanto, 2015).

\section{METODE PENELITIAN}

Penelitian dilaksanakan pada bulan Juni-Agustus 2018. Tempat pengambilan sampel di Kabupaten Pidie. Pengamatan morfologi Cucurbitaceae pada bagian batang, daun, bunga, buah, dan biji dilakukan di habitat aslinya. Data karakterisasi morfologi tumbuhan Cucurbitaceae yang diperoleh ditabulasikan untuk menghasilkan data kualitiatif dan kuantitatif berdasarkan variabel untuk masing-masing variasi tanaman yang diamati. Data hasil karakterisasi morfologi tumbuhan famili cucurbitaceae dianalisis dengan menggunakan software UPGMA-NTSYS untuk memperoleh dendogram hubungan kekerabatan.

\section{HASIL DAN PEMBAHASAN \\ Karakterisasi Tumbuhan Famili Cucurbitaceae di Kabupaten Pidie}

Berdasarkan penelitian yang telah dilakukan di Kabupaten Pidie Provinsi Aceh, ditemukan delapan jenis tumbuhan famili cucurbitaceae yang terdiri dari Cucumis sativus (mentimun), Luffa acutangula (gambas/oyong), Ligenaria siceria (labu air), Cucurbita moschata (waluh), Sechium edule (labu siam), Citrullus vulgaris (semangka), Cucumis melo (melon), dan Momordica charantia (pare).

Karakterisasi morfologi tumbuhan famili cucurbitaceae dilakukan dengan mengamati organ batang, daun, bunga, buah dan biji. Pengamatan morfologi batang meliputi bentuk, warna, diameter, panjang ruas dan sifat batang. Pengamatan morfologi daun meliputi bentuk, pertulangan, warna, diameter, panjang, lebar, panjang tangkai, dan permukaan. Pengamatan karakter morfologi pada bunga meliputi warna, sifat petala, panjang tangkai, panjang kelopak, panjang dan mahkota. Pengamatan karakter morfologi pada buah meliputi warna kulit, bentuk, panjang, diameter, sifat daging buah, ujung buah, pangkal buah, warna daging, permukaan dan sifat kulit buah. Pengamatan karakter morfologi biji meliputi bentuk, warna, permukaan, tepi, panjang dan lebar. Karakterisasi morfologi tumbuhan famili cucurbitaceae dapat dilihat pada tabel 1 . 
Tabel 1. Karakterisasi Morfologi Tumbuhan Famili Cucurbitacea

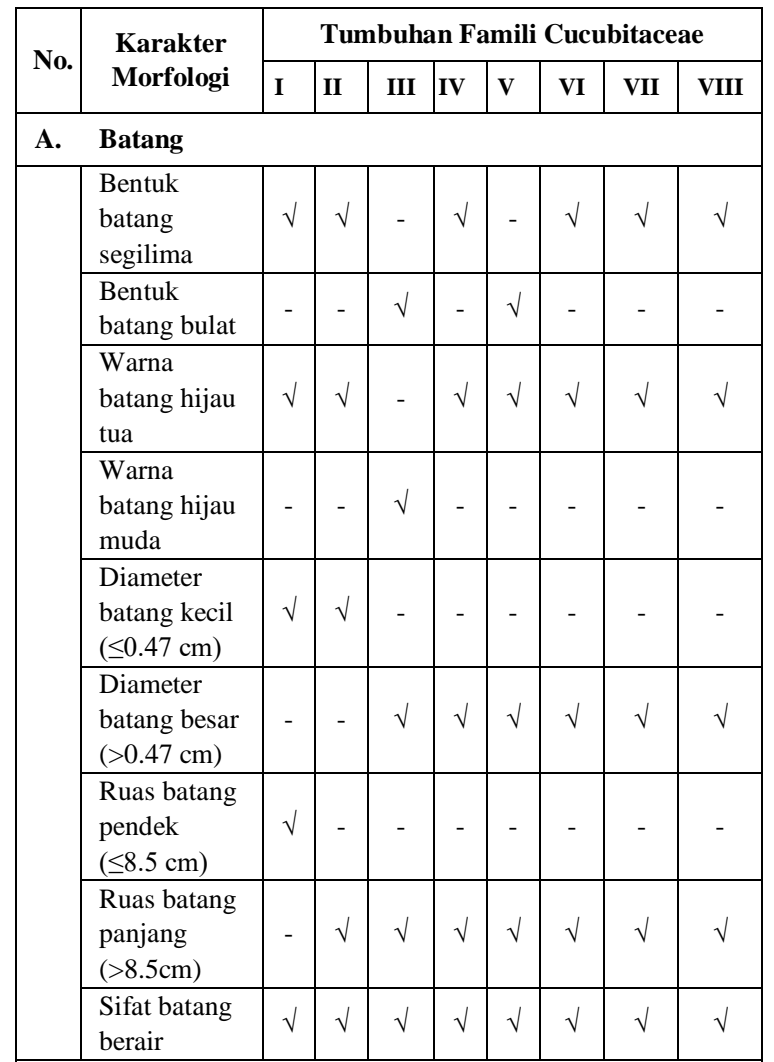

\section{B. Daun}

\begin{tabular}{|c|c|c|c|c|c|c|c|c|}
\hline $\begin{array}{l}\text { Pertulangan } \\
\text { daun } \\
\text { menjari }\end{array}$ & $\sqrt{ }$ & $\sqrt{ }$ & $\sqrt{ }$ & $\sqrt{ }$ & $\sqrt{ }$ & $\sqrt{ }$ & $\sqrt{ }$ & $\sqrt{ }$ \\
\hline $\begin{array}{l}\text { Bentuk daun } \\
\text { bulat }\end{array}$ & $\sqrt{ }$ & $\sqrt{ }$ & $\sqrt{ }$ & - & - & $\sqrt{ }$ & $\sqrt{ }$ & - \\
\hline $\begin{array}{l}\text { Bentuk daun } \\
\text { jantung }\end{array}$ & - & - & - & $\sqrt{ }$ & $\sqrt{ }$ & - & - & $\sqrt{ }$ \\
\hline $\begin{array}{l}\text { Warna daun } \\
\text { hijau tua }\end{array}$ & $\sqrt{ }$ & $\sqrt{ }$ & $\sqrt{ }$ & $\sqrt{ }$ & $\sqrt{ }$ & $\sqrt{ }$ & $\sqrt{ }$ & $\sqrt{ }$ \\
\hline $\begin{array}{l}\text { Diameter } \\
\text { kecil }(\leq 11.3 \\
\mathrm{cm})\end{array}$ & - & - & - & - & - & - & - & $\sqrt{ }$ \\
\hline $\begin{array}{l}\text { Diameter } \\
\text { besar }(>11.3 \\
\mathrm{cm})\end{array}$ & $\sqrt{ }$ & $\sqrt{ }$ & $\sqrt{ }$ & $\sqrt{ }$ & $\sqrt{ }$ & $\sqrt{ }$ & $\sqrt{ }$ & - \\
\hline $\begin{array}{l}\text { Daun } \\
\text { Pendek } \\
(\leq 13.2 \mathrm{~cm})\end{array}$ & - & - & - & - & - & - & - & $\sqrt{ }$ \\
\hline $\begin{array}{l}\text { Daun } \\
\text { panjang } \\
(>13.2 \mathrm{~cm})\end{array}$ & $\sqrt{ }$ & $\sqrt{ }$ & $\sqrt{ }$ & $\sqrt{ }$ & $\sqrt{ }$ & $\sqrt{ }$ & $\sqrt{ }$ & - \\
\hline $\begin{array}{l}\text { Daun sempit } \\
(\leq 11.3 \mathrm{~cm})\end{array}$ & - & - & - & - & - & - & - & $\sqrt{ }$ \\
\hline $\begin{array}{l}\text { Daun lebar } \\
(>11.3 \mathrm{~cm})\end{array}$ & $\sqrt{ }$ & $\sqrt{ }$ & $\sqrt{ }$ & $\sqrt{ }$ & $\sqrt{ }$ & $\sqrt{ }$ & $\sqrt{ }$ & - \\
\hline $\begin{array}{l}\text { Tangkai } \\
\text { daun } \\
\text { panjang } \\
(\leq 7.9 \mathrm{~cm})\end{array}$ & - & - & - & - & - & - & - & $\sqrt{ }$ \\
\hline $\begin{array}{l}\text { Tangkai } \\
\text { daun pendek } \\
(>7.9 \mathrm{~cm})\end{array}$ & $\sqrt{ }$ & $\sqrt{ }$ & $\sqrt{ }$ & $\sqrt{ }$ & $\sqrt{ }$ & $\sqrt{ }$ & $\sqrt{ }$ & - \\
\hline
\end{tabular}

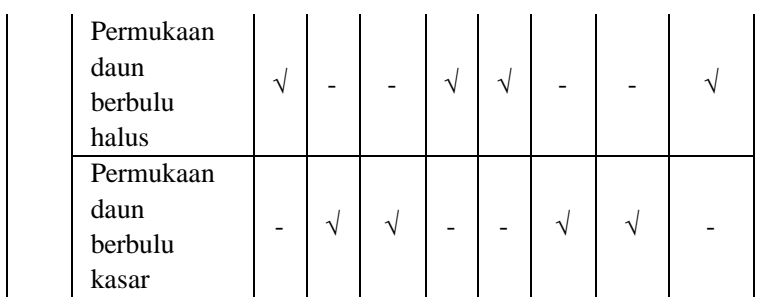

\section{Bunga}

Warna

bunga putih

warna bunga

kuning

Petala bebas

Petala

menempel

Tangkai

bunga

pendek

$(\leq 2.1 \mathrm{~cm})$

Tangkai

bunga

panjang

$(>2.1 \mathrm{~cm})$

Kelopak

pendek

$(\leq 0.5 \mathrm{~cm})$

Kelopak

panjang

$(>0.5 \mathrm{~cm})$

Mahkota

pendek

$(\leq 1.3 \mathrm{~cm})$

Mahkota

panjang

$(>1.3 \mathrm{~cm})$

\section{Buah}

Warna kulit

buah hijau,

tidak bercak

Warna kulit

buah hijau,

bercak

Bentuk buah

bulat

Bentuk buah

bulat

panjang

Daging buah

penuh

Daging buah

berongga

Ujung buah

rata

Ujung buah

runcing

Pangkal

buah rata

Pangkal

buah

berlekuk

Warna

daging buah

putih 


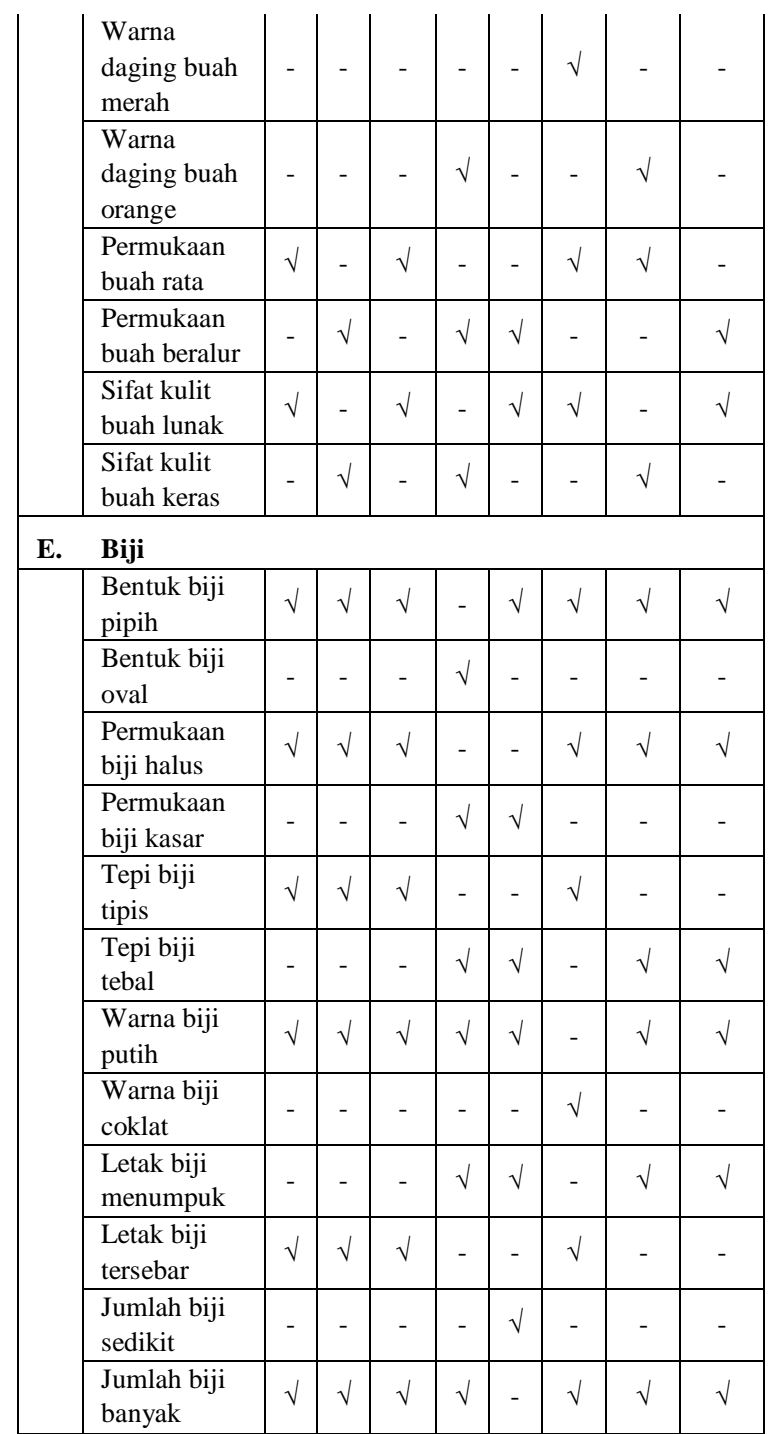

Keterangan :

I. Cucumis sativus (mentimun), II. Luffa acutangula (gambas/oyong), III. Ligenaria siceria (labu air), IV. Cucurbita moschata (waluh), V. Sechium edule (labu siam), VI. Citrullus vulgaris (semangka), VII. Cucumis melo (melon), dan VIII. Momordica charantia (pare).

Berdasarkan ciri morfologi akan dibahas satu persatu mengenai organ tanaman yang diamati di lapangan sehingga akan diketahui keragaman dari masingmasing variasi morfologi tumbuhan famili cucurbitaceae.

\section{Batang}

Batang merupakan organ tumbuhan yang terdapat di atas permukaan tanah, berfungsi sebagai penopang tumbuhan, transportasi air, penimbun cadangan makanan dan hasil fotosintesis. Hasil karakterisasi batang tumbuhan famili cucurbitaceae menunjukkan adanya perbedaan pada diameter dan panjang ruas batang. Sifat batang berair dengan bentuk segilima dan berwarna hijau muda hingga hijau tua.
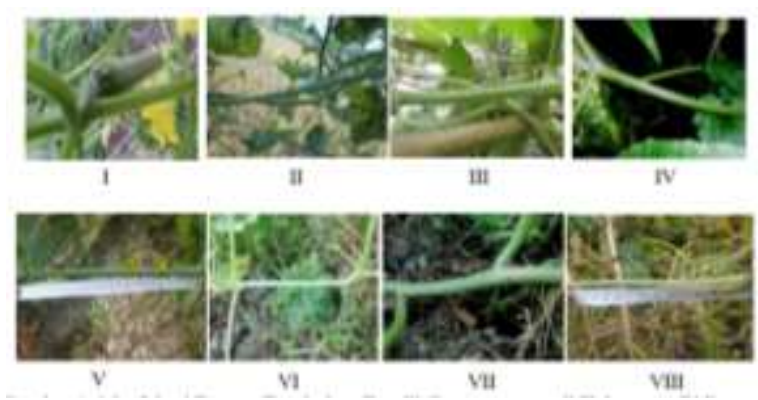

Gambar 1. Morfologi Batang Tumbuhan Famili Cucurbitaceae di Kabupaten Pidie I. Cucumis sativus (mentimun), II. Luffa acutangula (gambas/oyong), III. Ligenaria siceria (labu air), IV. Cucurbita moschata (waluh), V. Sechium edule (labu siam), VI. Citrullus vulgaris (semangka), VII. Cucumis melo (melon), dan VIII. Momordica charantia (pare).

\section{Daun}

Hasil karakterisasi organ daun menunjukkan bahwa bentuk daun tumbuhan famili cucurbitaceae terdiri dari bentuk jantung dan bulat. Sechium edule (labu siam), Citrullus vulgaris (semangka) dan Momordica charantia (pare) memiliki bentuk jantung, sedangkan jenis lainnya memiliki bentuk bulat. Daun berwarna hijau tua dan tepi daun rata dan berlekuk. Terdapat perbedaan pada diameter, panjang dan lebar daun.
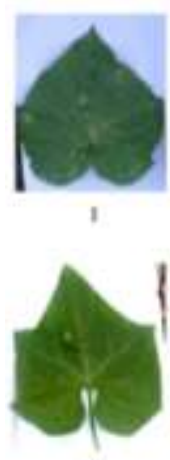

$\checkmark$

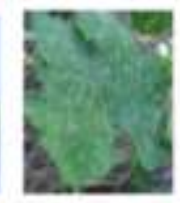

if

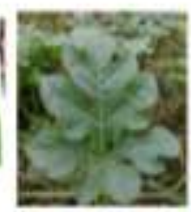

vi

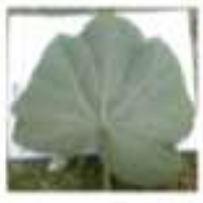

aI

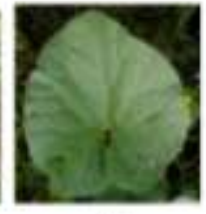

VII

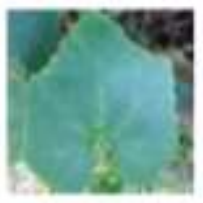

NV

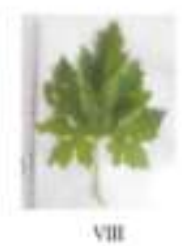

Gambar 2. Morfologi Daun Tumbuhan 
Famili Cucurbitaceae di Kabupaten Pidie

I. Cucumis sativus (mentimun), II. Luffa acutangula (gambas/oyong), III. Ligenaria siceria (labu air), IV. Cucurbita moschata (waluh), V. Sechium edule (labu siam), VI. Citrullus vulgaris (semangka), VII. Cucumis melo (melon), dan VIII. Momordica charantia (pare)

\section{Bunga}

Bunga merupakan organ reproduksi pada tumbuhan. Hasil karakterisasi morfologi bunga pada tumbuhan famili cucurbitaceae menunjukkan adanya perbedaan pada warna, petala, panjang tangkai, kelopak dan mahkota. Bunga tumbuhan famili cucurbitaceae memiliki kelopak dan mahkota berjumlah 5 (lima). Ligenaria siceria (labu air) dan Sechium edule (labu siam) memiliki bunga berwarna putih, sedangkan jenis lainnya berwarna kuning.
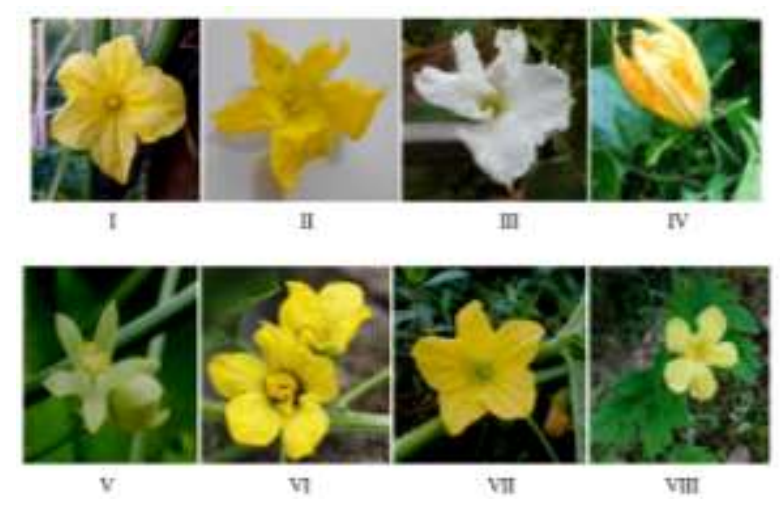

Gambar 3. Morfologi Bunga Tumbuhan Famili Cucurbitaceae di Kabupaten Pidie

I. Cucumis sativus (mentimun), II. Luffa acutangula (gambas/oyong), III. Ligenaria siceria (labu air), IV. Cucurbita moschata (waluh), V. Sechium edule (labu siam), VI. Citrullus vulgaris (semangka), VII. Cucumis melo (melon), dan VIII. Momordica charantia (pare)

\section{Buah}

Hasil karakterisasi morfologi buah pada tumbuhan famili cucurbitaceae menunjukkan bahwa adanya variasi morfologi buah meliputi bentuk, warna kulit buah, daging buah, ujung, pangkal, warna daging, alur buah dan sifat kulit buah. Bentuk buah bulat panjang terdapat pada Cucumis sativus (mentimun), Luffa acutangula (gambas/oyong), Ligenaria siceria (labu air), Cucurbita moschata (waluh), dan Momordica charantia (pare). Umumnya kulit berwarna hijau dan tidak bercak, kecuali buah Cucumis sativus (mentimun), Citrullus vulgaris (semangka) dan Cucumis melo (melon) memiliki kulit bercak. Sifat kulit keras terdapat pada Luffa acutangula (gambas/oyong), Cucurbita moschata (waluh), dan Cucumis melo (melon).

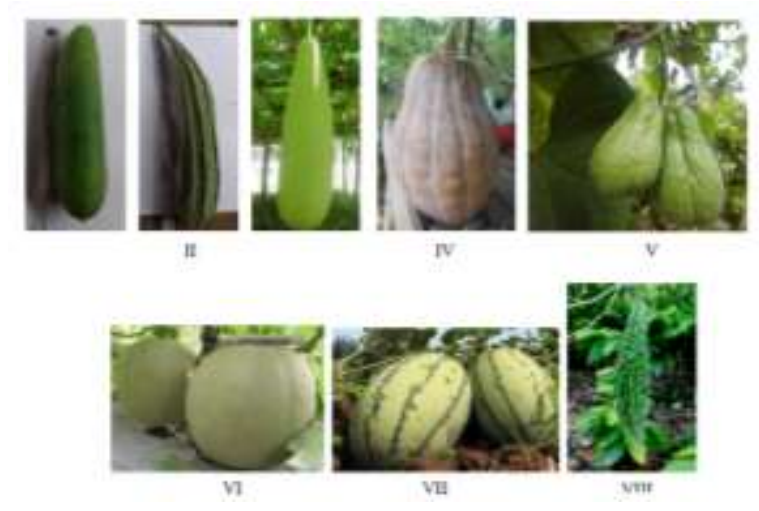

Gambar 4. Morfologi Buah Tumbuhan Famili Cucurbitaceae di Kabupaten Pidie

I. Cucumis sativus (mentimun), II. Luffa acutangula (gambas/oyong), III. Ligenaria siceria (labu air), IV. Cucurbita moschata (waluh), V. Sechium edule (labu siam), VI. Citrullus vulgaris (semangka), VII. Cucumis melo (melon), dan VIII. Momordica charantia (pare)

\section{Dendogram Hubungan Kekerabatan Tumbuhan Famili Cucurbitaceae Berdasarkan Karakter Morfologi}

Kesamaan karakter yang teramati dari delapan jenis tumbuhan famili cucurbitaceae dalam penelitian ini dapat menunjukkan kedekatan dalam hubungan kekerabatan yang dimiliki oleh delapan jenis tumbuhan famili cucurbitaceae tersebut. Hubungan kekerabatan dianalisis dengan memberikan nilai 1 apabila tanaman memiliki sifat karakter morfologi yang diamati dan diberi nilai 0 apabila tidak memiliki karakter yang diamati. Dendrogram yang terbentuk merupakan dendrogram dari hasil NTSYS. 


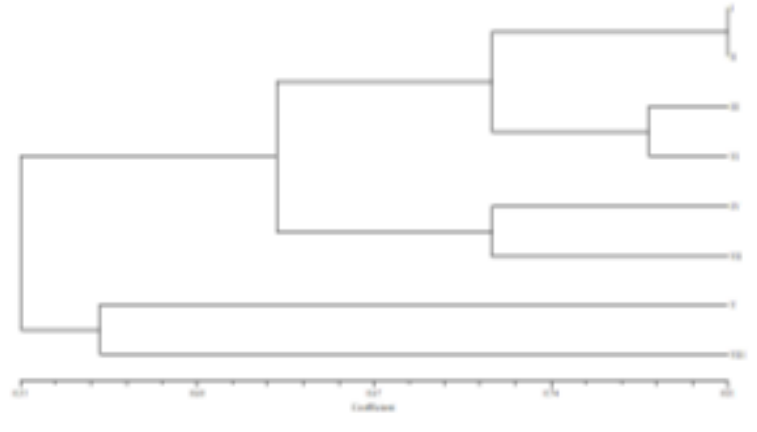

Gambar 5. Dendogram Hubungan Kekerabatan Berdasarkan Karakter Morfologi

I. Cucumis sativus (mentimun), II. Luffa acutangula (gambas/oyong), III. Ligenaria siceria (labu air), IV. Cucurbita moschata (waluh), V. Sechium edule (labu siam), VI. Citrullus vulgaris (semangka), VII. Cucumis melo (melon), dan VIII. Momordica charantia (pare).

Pada koefisien kemiripan 0.67, dendogram dibagi menjadi 4 (empat) kelompok. Kelompok 1 terdiri dari Cucumis sativus (mentimun), Luffa acutangula (gambas/oyong), Ligenaria siceria (labu air), dan Citrullus vulgaris (semangka). Kelompok 2 terdiri dari Cucurbita moschata (waluh) dan Cucumis melo (melon). Kelompok 3 terdiri dari Sechium edule (labu siam). Kelompok 4 terdiri dari Momordica charantia (pare).

\section{KESIMPULAN}

Hasil penelitian menunjukkan bahwa terdapat variasi morfologi batang, daun, bunga dan buah pada tumbuhan famili cucurbitaceae. Koefisien kemiripan 0.67, dendogram dibagi menjadi 4 (empat) kelompok. Kelompok 1 terdiri dari Cucumis sativus (mentimun), Luffa acutangula (gambas/oyong), Ligenaria siceria (labu air), dan Citrullus vulgaris (semangka). Kelompok 2 terdiri dari Cucurbita moschata (waluh) dan Cucumis melo (melon). Kelompok 3 terdiri dari Sechium edule (labu siam). Kelompok 4 terdiri dari Momordica charantia (pare).

\section{DAFTAR PUSTAKA}

Aruah, C.b., M.I. Uguru, and B.C. Oyiga. 2010. Variations among some Nigerian Cucurbita Landcraces. African Journal of Plant Science 4(10): 374-386.

Caliskan, O. and A.A. Polat. 2012. Morphological Diversity among Fig (Ficus carica L.) Accesions Sampled from The Eastern Mediterranean Region of Turkey. Turkey Journal of Agriculture 36: 179-183.

Das, S.S., Sudarsono., H.M.H. Bintoro D., dan Yudiwanti W.E.K. 2012. Keragaman Spesies Pala (Myristica spp.) Maluku Utara Berdasarkan Penanda Morfologi dan Agronomi. Jurnal Littri 18(1): 1-9.

Deyo, Austin. 2008. Cucurbitacea diakses melalui http;//www. The plant family cucurbitacea. Pada Tanggal 27 Mei 2017

Fu, C., H.Shi. and Q.Li. 2006. A Review on Pharmacological Activities and Utilization Technologies of Pumpkin. Plant Foods for Human Nutrition 61(2): 73-80.

Jones Sb and Luchsinger Ae. 1987. Plant Systematics. Singapore: McgrawHill Book Company

Julisaniah, N.I., Liliek S., dan Arifin N.S. 2008. Analisis Kekerabatan Mentimun (Cucumis sativus L.) Menggunakan Metode RAPD-PCR dan Isozim. Jurnal Biodiversitas 9(2): 99-102.

Lopez, D.G., M.S. Figueroa. L.A. Anaya and N.M. Perez. 2010. Morphological Characterization of Native Mangos from Chiapas, Mexico. Subtropical Plant Science 62 : 18-26. 
Luitel, B.P., P.B. Adhikari, S.L. Shrestha, and W.H. Kang. 2012. Morphological Characterization of Anther Derived Plants in Minipaprika (Capsicum annuum L.). Korean Journal of Breeding Science 44(4): 450-461.

Melati. 2009. Pembungaan dan penyerbukan pada jambu mete (Anacardium occidentale L.). Perkembangan Teknologi TRO. 21(2)56-63.

Renner, Susanne.S., and Schaefer, Hanno. 2016. Phylogeny and Evolution of The Cucurbitacea. Gemary: University of Munich.

Rideng, I Made. 1989. Taksonomi Tumbuhan Berbiji. Jakarta: P2LPTK.

Saboo, S.s., Priyanka K. Thorat. Ganesh G. Tapadiya, S.s. Khadabadi. 2003. Ancient and Recent Medical Uses of Cucurbitaceae Family. International Journal of Therapeutic Applications. Vol. 9: 11-19.

Schaefer,Hanno.,Kocyan,Alexander.,dan Re nner,S.Susanne. 2008. Linnaeosicyos (Cucurbitacea): a New Genus for Trichosanthes amara, the Caribbean Sister Species of all Sicyeae. Germany: Systematic botany Departement of Biology University of Munich.

Shirsat, R., P. Kokate. and S. Surdakar. 2012. Morphological and Anatomical Characterization of Salvia pleibea from Maharashtra (India). Bioscience Discovery 3(2): 165168.

Simpson. 2006. Plant Systematics. New York: Elsevier Academic Press.
Sitompul, S.M., dan B. Guritno. 1995. Analisis Pertumbuhan Tanaman. Gadjah mada University Press. Yogyakarta.

Suranto. 2001b. Pengaruh Lingkungan Terhadap Bentuk Morfologi Tumbuhan: Could The Enviromental Influences Determine The Plant Morphology. Enviro 1 (2): 772-775.

Teppner, Herwig. 2004. Notes on Lagenaria and Cucurbita (Cucurbitaceae) Review and New Contributios. Austria Phyton: Vol 44PP: 245-308 diakses melalui http; www. biologiezentrum.at. Pada Tanggal 28 Mei 2017. 